\title{
FOOD AND DRINK PROCESSING FROM LYCHEE PRODUCTS IN THE NORTHERN PROVINCES OF VIETNAM - AND ROLES OF AGRICULTURE PROJECT FINANCING
}

\author{
PROCESAMIENTO DE ALIMENTOS Y BEBIDAS A PARTIR DE PRODUCTOS \\ DE LECHE EN LAS PROVINCIAS DEL NORTE DE VIETNAM Y PAPELES DEL \\ FINANCIAMIENTO DE PROYECTOS AGRÍCOLAS
}

\author{
Dinh Tran Ngoc-Huy ${ }^{1}$; Nguyen Thi Hang ${ }^{2}$ *; Le Thi Thanh-Huong ${ }^{3}$; Pham Van Hong ${ }^{4}$ \\ 1. Banking University HCMC, Ho Chi Minh city Vietnam - International University of Japan, Japan. \\ dtnhuy2010@gmail.com \\ 2. Thai Nguyen University, University of Information and Communications Technology, Vietnam.nthang@ictu.edu.vn \\ 3. Dai Nam University, Vietnam. lethanhhuong@dainam.edu.vn \\ 4. Vietnam Institute of Science, Technology and Innovation, Vietnam.phamvanhong1973@gmail.com \\ *Correspondencia del Autor: Nguyen Thi Hang. e-mail: nthang@ictu.edu.vn
}

\begin{abstract}
The purpose of this study focuses on presenting the food and drink process in the case of making lychee juice and lychee-tea combination fruit juice in a tropical country such as Vietnam. We mainly use methods of qualitative analysis, synthesis and inductive methods, with description and explanatory methods. Authors also use a value chain approach from a material supply (lychee products) to production and market distribution.

Research results show us that choosing good red lychee together with good green or black tea, esp. Lipton tea, which is produced from the region of material supplying in the Northern region of Vietnam, then mixed with sugar and ice, using little vegetables will be very good for everybody health, functioning as medical treatment to prevent heart disease, and helps men and women stronger.

In the meantime, we also propose lychee and tea planting policies and capital financing policies in the country, esp. In the north of Vietnam. For instance, the nation needs to continue to negotiate with countries that have not yet allowed Vietnam's fresh lychee to be imported into developed countries (such as Korea, ...); The state/province cooperates with donors and businesses in trade promotion activities in potential export markets for Vietnamese lychee and fruit products (Japan, Korea, US, EU, ASEAN...).
\end{abstract}

Keywords: lychee; lychee fruit juice; lychee-tea juice-making process; food and drink; Vietnam; agriculture planting policies.

\section{Cómo citar:}

Ngoc-Huy, Dinh Tran; Hang, Nguyen Thi; Thanh-Huong, Le Thi; Hong, Pham Van. (2021). FOOD AND DRINK PROCESSING FROM LYCHEE PRODUCTS IN THE NORTHERN PROVINCES OF VIETNAM AND ROLES OF AGRICULTURE PROJECT FINANCING. Revista de Investigaciones Universidad del Quindio, 33(1), 187-195. https://doi.org/10.33975/riuq.vol33n1.555 


\section{RESUMEN}

El propósito de este estudio se enfoca en presentar el proceso de alimentos y bebidas en el caso de hacer jugo de lichi y jugo de frutas combinado de lichi y té en un país tropical como Vietnam. Utilizamos principalmente métodos de análisis cualitativo, síntesis y métodos inductivos, con métodos descriptivos y explicativos. Los autores también utilizan un enfoque de cadena de valor desde el suministro de material (productos de lichi) hasta la producción y distribución en el mercado.

Los resultados de la investigación nos muestran que elegir un buen lichi rojo junto con un buen té verde o negro, especialmente. El té Lipton, que se produce a partir de la región de suministro de material en la región norte de Vietnam, luego se mezcla con azúcar y hielo, utilizando pequeñas verduras será muy bueno para la salud de todos, funciona como tratamiento médico para prevenir enfermedades cardíacas y ayuda a los hombres y mujeres más fuertes.

Mientras tanto, también proponemos políticas de siembra de lichi y té y políticas de financiamiento de capital en el país, esp. En el norte de Vietnam. Por ejemplo, la nación necesita continuar negociando con países que aún no han permitido que el lichi fresco de Vietnam sea importado a países desarrollados (como Corea, ...); El estado / provincia coopera con donantes y empresas en actividades de promoción comercial en posibles mercados de exportación de lichi y productos de frutas vietnamitas (Japón, Corea, EE. UU., UE, ASEAN...).

Palabras clave: lichi; jugo de fruta de lichi; proceso de elaboración de jugo de lichi-té; alimentos y bebidas; Vietnam; políticas de plantación agrícola.

JEL Classification: F35, O47, C23

\section{INTRODUCTION}

Industrialization in Vietnam has taken place quite rapidly in recent years, but agriculture is still an important support for households in rural and mountainous areas, where the poverty rate still accounts for the highest proportion. In 2016, about $42 \%$ of the workforce was still working in the agricultural sector. This is not only a sustainable livelihood of rural households, but it is also an important way to save labor in times of economic crisis.

The role is still important, but Vietnam's agricultural production currently has many weaknesses compared to other countries in the region when comparing the efficiency of using resources (land, water) and labor. As a result, agricultural production efficiency has tended to decrease in recent times. Specifically, Vietnam's annual average agricultural labor productivity growth also decreased from $2.7 \%$ in the 1990 1999 period to $2.5 \%$ in the $2000-2013$ period (World Bank, 2016). The average annual growth of TFP (total factor productivity) in the period 1990-2000 decreased from 2.86 to 2.18 in the period 2006-2010 (OECD, 2015).

In this study we emphaizes on lychee product planting/growing in the north of VIetnam, and the drink process of making lychee juice and lychee-tea fruit juice.

Lychee-tea juice has brought to consumers many benefits such as: Lychee helps to strengthen the digestive system, cleans the stomach, improves appetite and cures heartburn as well as the feeling of stomach heat. Lychee also helps to boost energy levels in the body and contributes to the health of your whole family. Lychee seeds 
contain astringent substances that are used to treat gastrointestinal diseases and help the body eliminate intestinal worms. Lychees also contain soluble fiber that helps control intestinal problems and keeps the stomach free of toxic compounds as well as helps to clean the colon.

This paper organized with introduction, literature review, main results, discussion and conclusion.

\section{LITERATURE REVIEW}

First, Menzel (1984) stated that they found no relation between production of flower in lychee and the yield. Reason s involve : high ratio of premature flower and, especially, fruit abscission, a poor pollen transfer, low pollen viability and failure of pollen tube growth could reduce fruit set.

Then, Zhao et al (2020) said that There are many benefits from fresh lychee such as:good for biological activities, rich of vitamin and nutrition, etc.

The below table will summarize previous studies relating to our agriculture and food \& drink processing topic:

Table1 - Summarize previous studies

\begin{tabular}{|c|c|c|}
\hline Author names & Year & Results, contents \\
\hline 1.Zheng et al & (2008) & $\begin{array}{l}\text { There is low teperature }(13-16 \mathrm{oC}) \text { for processing lychee wine and } \\
\text { lychee juice. Then, we recognize fementation in } 8-10 \text { days. } \\
\text { Sugar: } 161.4 \mathrm{~g} / 1 \text {, acid: } 2.2 \mathrm{~g} / 1 \text { and } \mathrm{K}: 1251.8 \mathrm{mg} / \mathrm{l} \text {. } \\
\text { For lychee wine, we found out } 0.048 \mathrm{~g} / 1 \text { alcohols }\end{array}$ \\
\hline $\begin{array}{l}\text { 2.Sharma and } \\
\text { Ramarathinam }\end{array}$ & (2014) & $\begin{array}{l}\text { There are } 2 \text { coponents creating feature of lychee fruit juice : two } \\
\text { cultivars viz. cv. Dehradun and cv. There is a time or preservation } \\
\text { of } 6 \text { months. And temperature is at } 20-50^{\circ} \mathrm{C} \text { for rheological } \\
\text { behavior. }\end{array}$ \\
\hline 3.Lins et al & (2015) & $\begin{array}{l}\text { Layer of air done with Bengal seed which is healthy and leafy are } \\
\text { used in woody branches, diameter of } 0.015 \mathrm{~m} \text {. } \\
\text { Air layer - lychee are evaluated with impact of seasons and } \\
\text { subtrates for seedlings producing. }\end{array}$ \\
\hline 4.Zhao et al & (2020) & $\begin{array}{l}\text { Until now, in China, people use lychee, just as } 20 \text { countries in the } \\
\text { world, as drinks, fresh processed. } \\
\text { Also it is medical treatment (purpose of medicine) for stomach } \\
\text { ulcers and diabetes, with delicious flavor and high nutrition. }\end{array}$ \\
\hline $\begin{array}{l}\text { 5.Pham Van } \\
\text { Hong, Dinh Tran } \\
\text { Ngoc Huy, Le Thi } \\
\text { Thanh Huong et } \\
\text { al }\end{array}$ & (2021) & $\begin{array}{l}\text { There are several factors that affect Vietnam agriculture } \\
\text { sustainability such as: skills and experience of farmers, advanced } \\
\text { technology, agricultural engineering, standards and models such } \\
\text { as VIETGAP or GLOBAL GAP, etc. If comparing resources } \\
\text { efficiency use, the nation has many Weakness points in the region } \\
\text { in terms of land. water and labor. }\end{array}$ \\
\hline
\end{tabular}




\section{Data and Methodology}

-Value chain approach: The thesis uses the value chain approach to analyze the value chain including input supply - production - collection. Processing - consume); production and business linkages of related actors (farmers, enterprises, associations, the state...); approach in the way of upgrading added value in the chain.

Figure 1: Value chain analysis framework

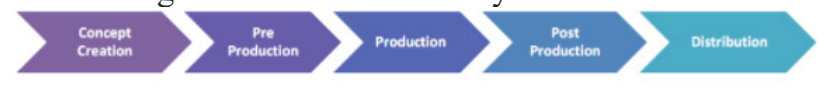

The basic elements in value chain analysis:

- Support services: financial services (financial services, credit, informal mobilization) and non-financial services (training courses, seminars/workshops, applications) technology use/transfer, industry support logistics, public and private consulting services, etc.)

- Links between actors in the chain: linkages and cooperation between actors in the value chain (farmers to farmers, farmers to businesses, ...)

- Market factors: market trends, price structure of final products and input materials, number of suppliers, participating markets and linkages between domestic and international suppliers.

- Production and business environment: regulations and policies related to product development and competitiveness

Figure 2: Upgrading agricultural value chains

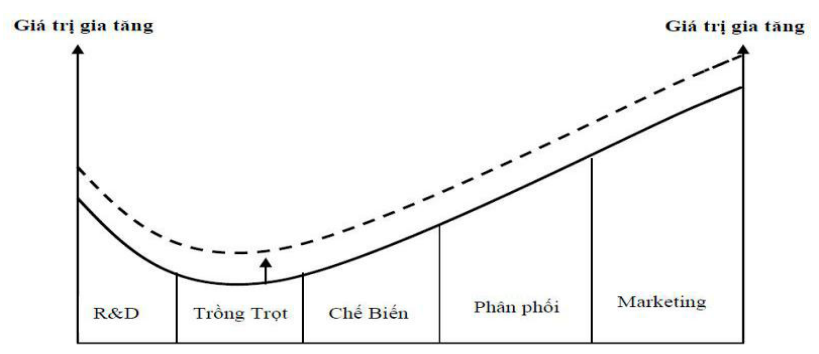

- Market/consumer driven approach: the research will use the market approach to clearly see the requirements/conditions and standards for products imported from Vietnam, especially high-end markets (developed countries) and the capacity to respond from the Vietnamese side for two specific products, lychee and tea. From there, find out the gaps between domestic agricultural production and the world market, find out the causes of restraints/limitations in order to have solutions to overcome and improve.

\section{MAIN FINDINGS}

\section{Raw materials - lychee products}

The first lychee tree was planted in Thanh Son commune, Thanh Ha district, Hai Duong province at the end of the 19th century. Then, in the 60 s of the 20th century, lychee trees were planted in Luc Ngan, Bac Giang, then the households. extended to other districts. Currently, the whole province of Bac Giang has nearly 30,000 hectares of lychee cultivation. In which, Luc Ngan is the largest lychee growing area in the country with more than 15,000 hectares. Lychees grown in Luc Ngan are larger than Thanh Ha lychees, and the price is also more expensive. The second largest lychee growing locality is Hai Duong province with 14,250 hectares, most concentrated in Thanh $\mathrm{Ha}(47 \%)$ and Chi Linh (43\%) districts (Thu Ha, 2017).

In terms of production output, Vietnam is one of the three largest lychee growing countries in the world, after China and India (Vietnam Trade Office in Australia, 2015). Depending on the weather situation, the annual production of lychee fruit in Vietnam fluctuates quite a lot. The total annual production of lychee in Vietnam ranges from 200-250 thousand tons, mainly in the two northern provinces of Bac Giang and Hai Duong. With over 28,000 ha of lychee growing area, lychee trees are creating many jobs and incomes for farmers in Bac Giang province. 
Figure 3 The main lychee growing countries on the world map

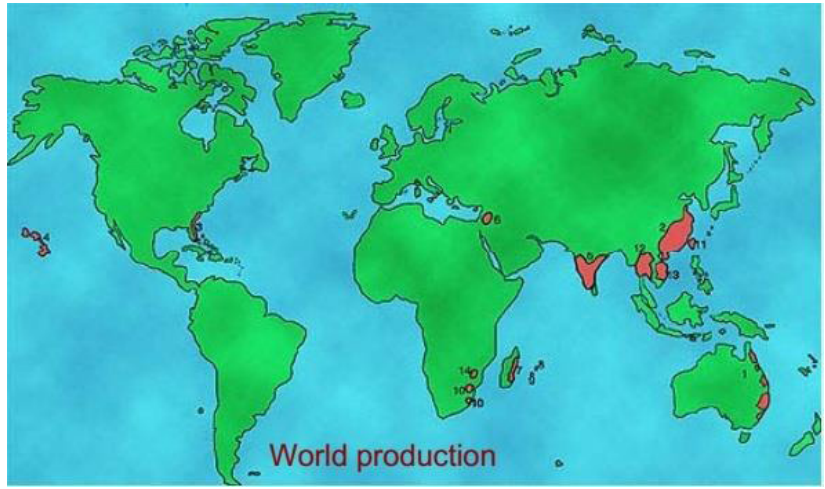

(Source: Christian, 2006)

Notes: 1-Australia; 2-China; 3- Florida, 4-Hawaii (USA); 5. India; 6 - Israel; 7-Madagascar; 8- Maurice; 9-Resunion; 10- South Africa; 11- Taiwan; 12- Thailand; 13-Vietnam.

Despite being the third largest producer in the world, Vietnam's lychee fruit is not really well known in developed countries' markets. Only a small amount has been exported

Table 1: Global lychee production

\begin{tabular}{|c|c|c|}
\hline & Country & Quantity (tons) \\
\hline & North of Globe & \\
\hline 1 & China & 1.482 .000 \\
\hline 2 & India & 624.000 \\
\hline 3 & Vietnam & 156.000 \\
\hline 4 & Taiwan & 80.000 \\
\hline 5 & Thailand & 43.000 \\
\hline 6 & Nepal & 14.000 \\
\hline 7 & Bangladesh & 13.000 \\
\hline 8 & Pakistan & 3.000 \\
\hline 9 & Mexico & 4.000 \\
\hline 10 & Israel & 1.200 \\
\hline 11 & USA & 600 \\
\hline \multirow[t]{2}{*}{12} & Others & 51.600 \\
\hline & South of Globe & \\
\hline 1 & Madagascar & 100.000 \\
\hline 2 & South Africa & 8.600 \\
\hline 3 & Australia & 6.000 \\
\hline 4 & Réunion & 12.000 \\
\hline 5 & Mauritus & 4.500 \\
\hline
\end{tabular}

Process of producing lychee fruit juice in Vietnam

\section{Process of making lychee juice}

This is to describe the process of making delicious lychee fruit juice in our country:

- Step 1: Preparation of ingredients for making lychee juice: Preliminary processing of ingredients for lychee juice; Peel the lychee, separate the pulp and separate it into a clean bowl; Cut the lemon in half, squeeze out the juice, remove the seeds. Put lychee meat and water into the juicer to get the juice.

- Step 2: Choose delicious lychee: choose the same size lychee, it looks bright, bright, red evenly, the thorns must be smooth, the fruit is large from the tip to the stem, when tasting the lychee fruit has a lot of water, has a sharp sweet taste and a strong aroma. show. In addition, the delicious lychee fruit has small, easy-to-separate seeds that are black in color. Depending on your taste, adjust the amount of lemon juice and sugar accordingly. Lychee juice has a very good use in whitening the skin, keeping the waist slim for women

Figure 4 - Choose good lychee for making juice

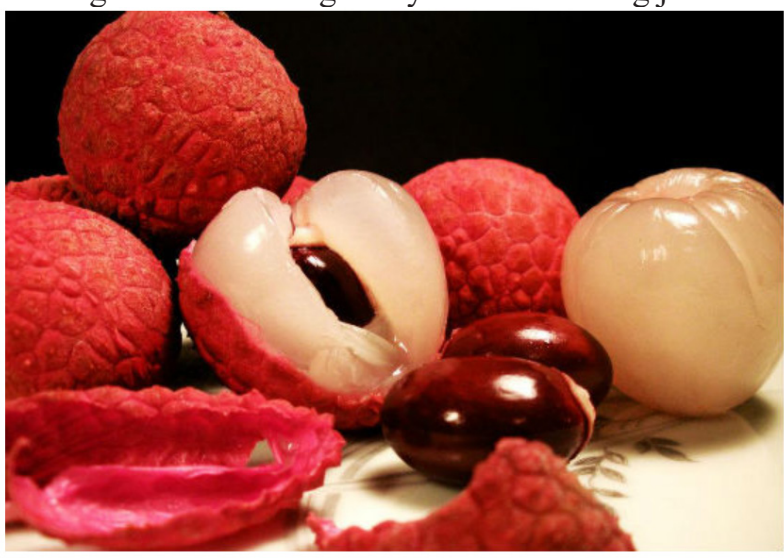

\section{Process of making lychee-tea juice}

First, we describe tea - material from Thai Nguyen Province, Vietnam:

Thai Nguyen province in Vietnam has produced Tan cuong tea, famous and other green tea or 
black tea which is good material to produce lipton tea, as we see in below figure

Figure 5 - Planting tea in Thai Nguyen province

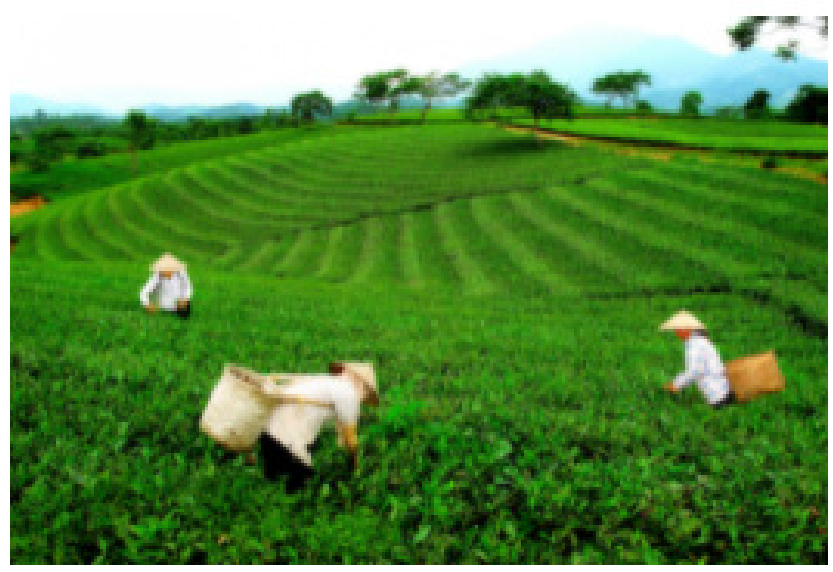

From Thai Nguyen tea, we can process to make green or black tea and material to produce lipton tea.

Process of making lychee-tea juice in our country:

Step 1 : choose good red lychee as the picture (above), together with sugar and little water.

Step 2: use tea (black tea or lipton tea)

Step 3: After that, add ice, lychee and fresh lychee into the glass depending on your taste like more or less. You can decorate a few sprigs of basil on top to make the lychee drink more eye-catching.

Then we can try to drink our delicious product as below figure showing:

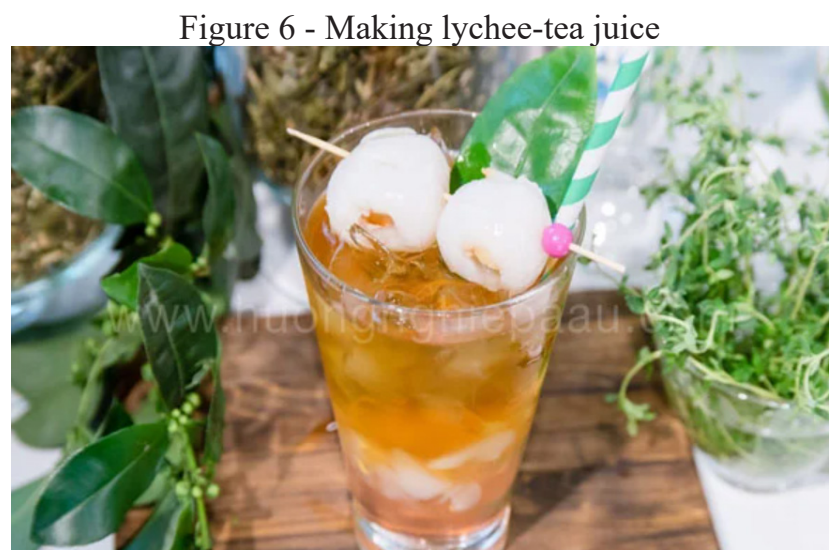

\section{Benefits of lychee fruit juice}

So you already know a recipe for a delicious, cool, healthy drink this summer, hopefully with this quick lychee juice recipe you'll have a bright white skin and a small waist. more compact after this summer.

From authors' own experience, if we use or drink 23 glasses of lychee fruit juice per week, we will feel more stronger and healthier (for both men and women) and more manly.

Lychee juice provide everybody with:

- rich in vitamin

- healthy with sugar less

- suitable for diet people as we can choose levels of sugar

- Lychee product means "gift for royalty". The benefits of lychee have been demonstrated in countries such as China or India and are recorded in ancient Chinese books.

- Cancer Prevention. This fruit contains flavonoids that help fight deadly diseases like cancer. It also contains flavones, quercitin and kaemferol which are powerful compounds that reduce the growth of cancer cells. Lychees have impressive properties that help prevent breast cancer.

- Heart disease prevention. Lychee helps to stabilize blood pressure and heart rate, thus helping to protect against stroke and cardiovascular disease. A glass of lychee juice a day helps return the heart rate to normal. Lychee also contains the second highest amount of polyphenols in fruits that help improve heart health. The antioxidants present in lychee improve the immune system, slow down the progression of degenerative retinal disease and prevent cardiovascular related diseases.

\section{DISCUSSION}

In terms of market access and product consumption, Vietnam's agricultural products are mainly sold in raw form, with no/or weak 
product brands, so they are often concentrated in easy-to-use markets with low selling prices. often low and the competitiveness is weak. Even in the domestic market, food safety and quality are still concerned (World Bank, 2016). For marketing and market search, due to the absence of participation of agricultural enterprises, the capacity to search and expand markets is still weak. Vietnamese agricultural products have not taken advantage of many opportunities from high-end markets. There are various reasons leading to this situation such as food quality and safety; low capacity and credit of suppliers/processors; the risks related to environmental traces in the production of agricultural products; Agricultural production is still fragmented and lacks linkages.

Specifically for lychee, although the selling price in developed markets (EU, Australia, Japan, ..) is much higher than the domestic market and the Chinese market. However, Vietnam's lychee still faces many limitations in accessing the high-end market. Currently, 55\% of Bac Giang's total lychee production (which accounts for most of Vietnam's lychee production) is consumed in the domestic market, $45 \%$ of the output is exported, but exports to the Chinese market account for $45 \%$ of the total lychee production. up to $88.7 \%$. There can be many different reasons leading to this result such as weak support service system, limited production and processing methods, high transportation costs, care, harvesting and preservation procedures. Due to poor handling, the quality control time in importing countries is prolonged, which reduces the competitiveness of products. In addition, some studies suggest that the lack of coordination and coordination among stakeholders in the fabric product chain also leads to low efficiency. Or this field has not attracted many businesses to participate, the cooperatives operate inefficiently, as well as inappropriate policies also affect the market participation of lychee.

\section{CONCLUSION}

There are various benefits from lychee and a combination of lychee-tea products.
Lychee juice and lychee-tea juice are very good and healthy for everybody, men and women, as well ass a good medical treatment for cancer and heart disease prevention.

Research results show us that choosing good red lychee together with good green or black tea, esp. Lipton tea, which is produced from the region of material supplying in the Northern region of Vietnam, then mixed with sugar and ice, using little vegetables will be very good dfor health and helps men and women stronger.

In below section, we introduce policies to encourage planting and growing lychee and tea in Vietnam, as well as project financing for agriculture in this sector.

\section{RECOMMENDATIONS ON POLICY IMPLICATIONS}

\section{Lychee planting policy suggestion:}

Invest in building a processing and supporting industry cluster/trade in lychee fruit (in Luc Ngan or Luc Nam provinces of Vietnam). Forming a concentrated production area of supporting products (styrofoam boxes, ice cubes) in order to increase the advantages of scale (power supply, water supply, information supply, transportation, etc.) Incentivize and attract investors to build a total (cold) warehouse to increase the storage time of lychee and other fruits

- Priority on land rent and tax for processing enterprises/signing long-term association contracts with lychee growers

- Continue to negotiate with countries that have not yet allowed Vietnam's fresh lychee to be imported into developed countries (such as Korea, ...)

- The state/province cooperates with donors and businesses in trade promotion activities in potential export markets for Vietnamese lychee and fruit products (Japan, Korea, US, EU, ASEAN...)

- Strictly enforce policies and regulations on 
food safety, on labeling for better product traceability right from the production stage. Mandatory regulations on the production of safe products, in the direction of clean production, are allowed to be supplied to the market.

\section{Tea planting policy suggestion:}

Based on this strategic orientation, Thai Nguyen province needs to develop a development strategy based on product quality for the tea industry and should be placed in a long-term vision, instead of simply relying on phased projects. passage as it is today. This strategy should identify and plan the development of high quality tea areas with internationally recognized production standards. This production area will produce tea products with high hygiene and safety standards, excellent quality to target high-end customers and export markets of medium and above.

Thai Nguyen province needs to have a strategy to attract investment for the innovation and improvement of tea processing technology with the aim of diversifying products to be able to take advantage of by-products from finished tea and from tea trees after harvesting. bud plan. Thai Nguyen should set a goal of building a brand in addition to the current traditional drinking tea, such as organic tea bags, to be internationally recognized and comparable to other brands like Dilmah or Lipton. This requires investment in the development of a research and application (R\&D) center, possibly located in a high-quality tea region.

\section{The solution to promote growth in lychee and tea production from bank financing}

For agriculture (lychee-tea) project financing:

- Commercial banks in Vietnam (Agribank, VCB, $\mathrm{ACB}, \mathrm{SHB}$, etc.) can offer preferential rates fr financing and loan packages to agriculture sectors and farmers together with supporting policies to develop lychee and tea markets from exporting policies and others.

- Enterprise type funding must be used into projects that benefit small and emerging businesses up in rural areas as specified by the application for subsidies.

- Training and technical support, such as planning projects, business consulting/ training, market research field, feasibility study, technical/technical report technology, or product/service improvement

- Acquisition or development of land, land rights, or rights to build, convert, renovate buildings, factory, machine, equipment, street access, beach parking, utilities

- Pollution control and waste treatment

- Revolving loan fund capital includes funds that will make loans for startups and working capital

- Adult distance learning program for training and career advancement

- Improve rural transport

- Community economic development

- Technology-based economic development

- Feasibility study and business plan

- Training of leaders and entrepreneurs

- $\quad$ Space to rent for rural business

- Planning long-term business strategy

\section{LIMITATION OF THE RESEARCH}

We need to compare our country experience in producing lychee- tea fruit juice to other neighbor countries experiences in Asia such as Thailand and China and India, etc. 


\section{REFERENCES}

1. Akramov, Kamiljon T., 2012. Foreign aid allocation, governance, and economic growth, International Food Policy Research Institute, 7(2), 4-12.

2. Addison, T., \& Tarp, F. (2015). Aid policy and the macroeconomic management of aid, Journal of World Development, 69,1-5.

3. Amadeo, K. \& Linkedin, F. (2020), Economic Growth, Its Measurements, Causes, and Effects, How It's Measured and What Are the Causes, World Economy Review, Investopedia Pub., US.

4. Bui Thi Suu, Vu Quang Giang, Vu Phuong Lien, Dinh Tran Ngoc Huy, Ha Thi Lan. (2021). The Auto-infection Trap with the Native Entomopathogenic Fungus, Beauveria Bassiana for Management of Coffee Berry Borer (Stephanoderes Hampei Ferrari) in the Northwest Region of Vietnam, Alinteri Journal of Agriculture cience, 36(1). DOI: 10.47059/alinteri/V36I1/AJAS21028

5. Hong, P.V., Nguyen, N.T., Huy, D.T.N., Thuy, N.T., Huong, L.T.T. (2021). Evaluating Several Models of Quality Management and Impacts on Lychee Price Applying for Vietnam Agriculture Products Value Chain Sustainable Development, Alinteri Journal of Agriculture Science, 36(1): 122-130.

6. Menzel, C.M. (1984). The pattern and control of reproductive development in lychee: A review, Scientia Horticulturae, 22(4): 333-345

7. Lins, L.C.R., Salomao, L.C.C., Cecon, P.R., \& Siqueira, D.L.D. (2015). The Lychee tree propagation by layering, Rev. Bras. Frutic. vol.37 no.2 Jaboticabal Apr./June 2015. https://doi. org/10.1590/0100-2945-112/14

8. Sharma, R., \& Ramarathinam, M. (2014). Rheological behavior of litchi juice concentrates during storage, International Food Research Journal 21(3):1169-1176

9. Szirmai, A. \& Verspagen, B. (2015). Manufacturing and Economic Growth in Developing Countries,

10. 1950-2005, Structural Change and Economic Dynamics Journal, 34(2015): 46-59.

11. United Nations (2015). General Assembly resolution 70/1, Transforming our world: the 2030 Agenda for Sustainable Development., US.

12. Zhao, L., Wang, K., Zhu, J., \& Hu, Z. (2015). Nutrient components, health benefits, and safety of litchi (Litchi chinensis Sonn.): A review, Comprehensive Review in Food Science and Food Safety, 19(4).https://doi.org/10.1111/1541-4337.12590

13. Zeng, X.A., Qin, F.G.F., \& Zhang, L. (2008). Composition Analysis of Litchi Juice and Litchi Wine, International Journal of Food Engineering 4(4). DOI:10.2202/1556-3758.1379 